\title{
Hudebně talentovaní dospívající a přijímací řízení
}

\author{
Jiří Mareš a , Vladimír Tichýb \\ ${ }^{a}$ Univerzita Karlova v Praze, Lékařská fakulta v Hradci Králové \\ ${ }^{\mathrm{b}}$ Akademie múzických umění v Praze, Hudební a taneční fakulta
}

\section{Redakci zasláno 22.11. 2013 / upravená verze obdržena 23. 5. 2015 /}

k uveřejnění přijato 25. 5. 2015

\begin{abstract}
Abstrakt: Cílem přehledové studie je charakterizovat problémy, které souvisejí s vyhledáváním hudebních talentů a s talentovými zkouškami na vysoké školy s hudebním zaměřením. V první části tato studie přibližuje různá pojetí pojmů nadání a talent i jejich vzájemných vztahů. Ve druhé části definuje pojmy hudební nadání, hudební talent a hudební schopnosti. Třetí část studie analyzuje podobu talentových zkoušek na tři vysoké hudební školy v České republice (HAMU Praha, JAMU Brno a FU Ostrava). Studie diskutuje problémy spojené s komisionálním zkoušením uchazečů při přijímacím řízením a naznačuje možná řešení. Čtvrtá část se detailněji zabývá výhodami a nevýhodami urychlování vývoje u hudebně talentovaných studentů, tj. případy, kdy jsou přijati bez maturity, a dokládá je reálnými daty. Závěr: má-li přijímací rízení dobře plnit svou predikční funkci při vybírání těch nejlepších studentů z celého souboru uchazečů, musí se opírat o mnohem širší spektrum validních informací než dosud.
\end{abstract}

Klíčová slova: nadání, talent, hudební talent, přijímací řízení, vysoká umělecká škola, urychlování vývoje

Každý stát má zájem na tom, aby jeho kulturní úroveň reprezentovali dobře připravení a umělecky úspěšní hudebníci. Základem takové př́ípravy je jistě kvalitní povinná výuka hudební výchovy na základních školách a odborně vedená hudebně zájmová činnost dětí a dospívajících na základních uměleckých školách. Na druhém pólu této přípravy stojí specializované studium na vysoké škole s hudebním zaměřením.

V České republice fungují tři hudebně zaměřené fakulty. Historicky vzato jde o Hudební a taneční fakultu AMU v Praze, Hudební fakultu JAMU v Brně a Fakultu umění OU v Ostravě. Uchazeč o takovou př́ípravu, která začíná bakalářským studiem (at' už se jedná o hru na nástroj, zpěv, skladbu atd.), musí projít náročným přijímacím řízením. Jeho důležitou součástí je praktická zkouška. Výběr talentovaných a perspektivních studentů z řady uchazečů 
není jednoduchou záležitostí a je předmětem odborných diskusí ve všech vyspělých zemích.

Naše přehledová studie si klade tyto cíle: 1 . shrnout současné poznatky o pojmech nadání a talent; 2 . charakterizovat pojem hudební talent; 3. diskutovat problematiku přijímacího řízení a jeho predikční validity.

\section{Různá pojetí nadání a talentu}

V pedagogicko-psychologické literatuře se stále debatuje o vztahu mezi dvěma základními pojmy: nadání (giftedness) a talent (talent). Přehled názorů na tyto pojmy a na práci s těmito žáky ve škole shrnuje Mareš (2013). S určitým zjednodušením můžeme říci, že existují tři přístupy. Jejich podstatu přibližuje tabulka 1.

Existuje ještě jedno pojetí - eklektizující, které staví na analýze mnoha publikovaných prací a pokouší se o jistá zobecnění. Tým Nijsová, GallardoGallardová, Dries a Sels (2014) analyzoval práce zveřejněné od roku 1993 do současnosti, které se zabývají pojmem talent. Dospěl k této souhrnné definici:

Talentem se rozumí jednak systematicky rozvíjené vrozené schopnosti (tj. jeho schopnostní složka), jednak rozvíjení těchto schopností v aktivitách, které má jedinec rád, považuje je za důležité a do kterých je ochoten investovat svoji energii (afektivně-motivační složka). To mu umožňuje podávat vynikající výkony v jedné nebo více oblastech lidského fungování. Vynikající výkony lze měřit jak porovnáváním jedince $\mathrm{s}$ druhými lidmi, tak porovnáváním jedince s ním samotným v prủběhu času. (s. 182)

První část definice poukazuje na skutečnost, že se autoři přiklánějí ke koncepci Gagného $(2003,2004)$, tedy ke třetímu pojetí uvedenému v naší tabulce.

V naší studii volíme toto pojetí i my. Staví na myšlence, že nestačí mít předpoklady pro určitou činnost, ale je třeba, aby: (a) byly tyto předpoklady odhaleny, identifikovány; (b) jedinec se ztotožnil s tím, že takové předpoklady má (stanou se součástí jeho identity), že chce a může je uplatnit; (c) vyvinul snahu (byl motivován nejprve rodiči, poté svými učiteli a nakonec motivoval sám sebe) a své předpoklady zdokonaloval, cíleně rozvíjel.

Nejde však jenom o obecné úvahy o talentu. V každé oblasti lidské činnosti má talent svá specifika, včetně hudby. 


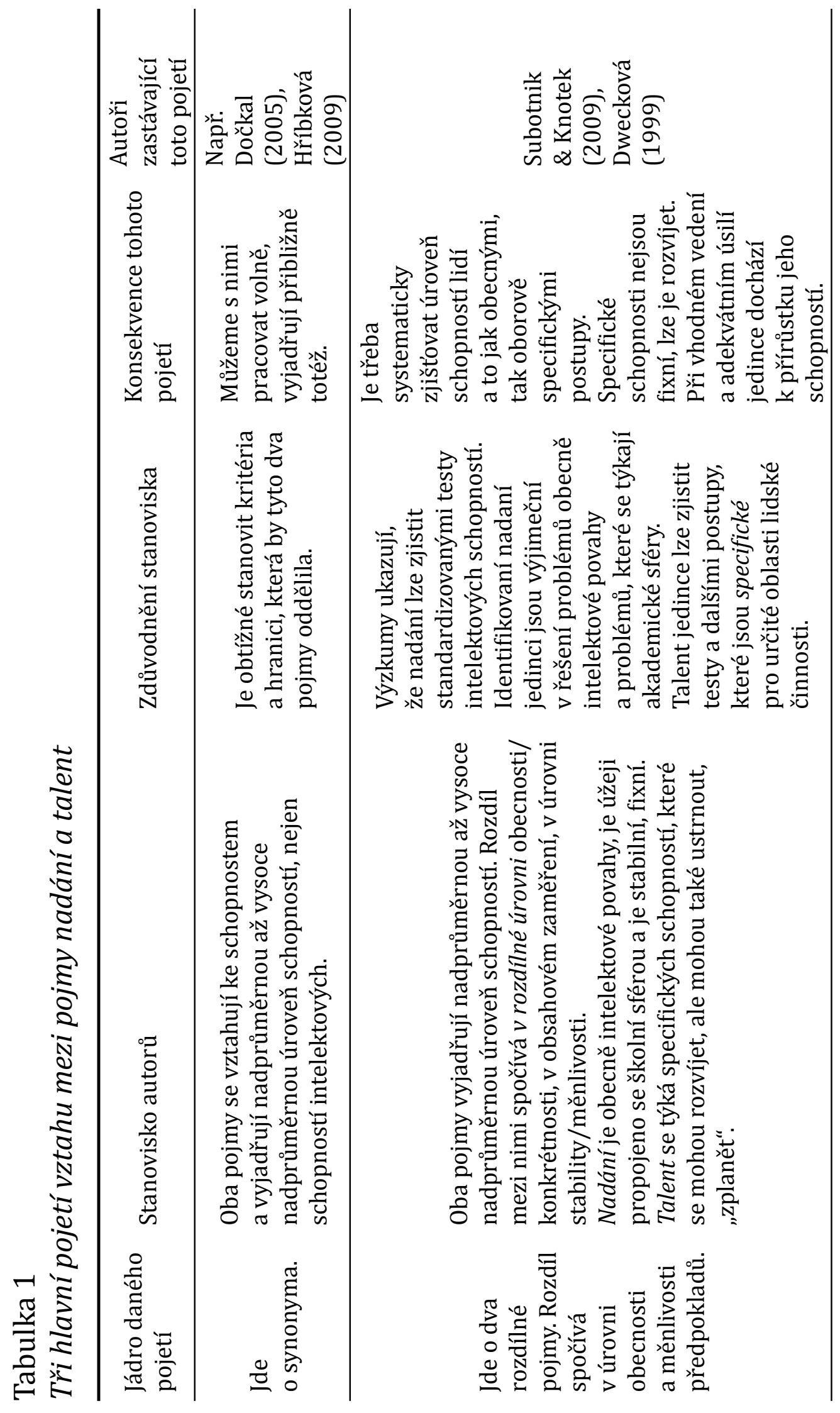




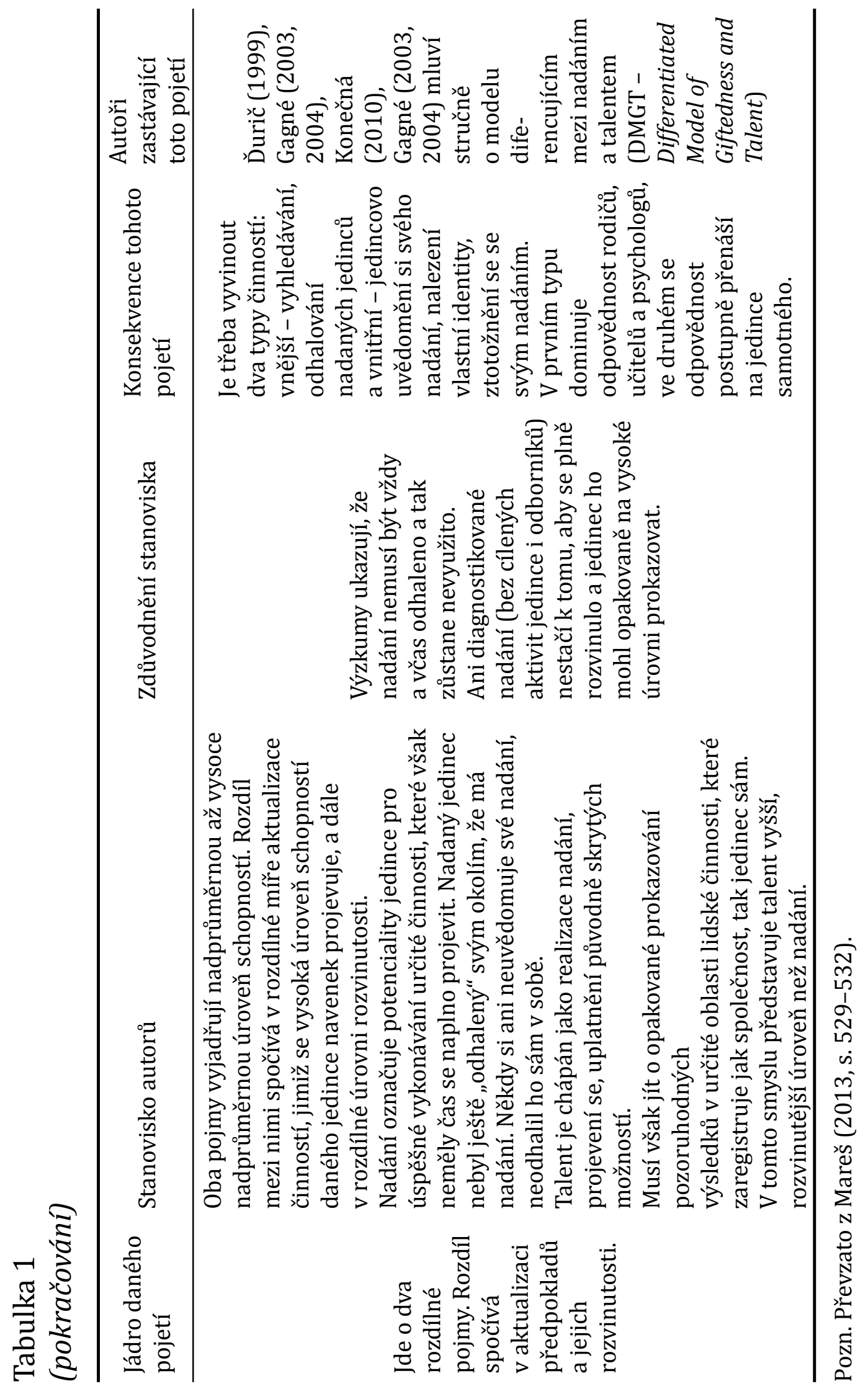




\section{Hudební nadání a hudební talent}

Jak se na tyto problémy dívá hudební psychologie? V domácích pracích se v podstatě akcentují jen tři pojmy: vlohy, schopnosti, nadání, zatímco pojem talent se používá málokdy. V základním rozdělení se odborníci shodují: prvotní je hudební nadání či hudební vlohy.

Hudební nadání tvoří vrozené a dědičné předpoklady hudebního rozvoje. Zahrnují jednak anatomický a neuropsychický základ, který je dán zčásti dědičností, jednak vlohovou výbavu určitého typu, např. psychofyziologickými kvalitami mikrostruktury mozku, nervové soustavy a analyzátorů, zvláště sluchového a pohybového (Poledňák, 1984; Franěk, 2007; Sedlák \& Váňová, 2013). Někteří autoři pracují spíše s pojmem vlohy, nikoli s nadáním. Např. Franěk (2007) vlohami rozumí vrozené dispozice pro určitou činnost, které odpovídají pojmu nadání. Sedlák a Váňová (2013, s. 50-52) uvádějí, že hudební vlohy tvoří základ pro emocionální citlivost $\mathrm{k}$ hudbě, ke způsobu hudebního vnímání, k úrovni hudební aktivity jedince a celkového vztahu k hudbě.

Nejde o jednu ucelenou entitu, naopak hudební nadání lze podle Poledňáka (1984) kvantitativně odstupňovat, ${ }^{1}$ ale vedle toho existuje i aspekt kvalitativní - svéráznost spojení různých dispozic a vloh. Také Sedlák a Váňová (2013) pracují s odstupňovanou podobou nadání a říkají, že výrazné hudební vlohy se v hudebním vývoji jedince často nápadně projevují už v raném dětství a označují se jako hudební nadání. Tvoří plastický dispoziční základ, multipotencialitu, jež se učením zužuje a dostává určité zaměření, a to podle hudební výchovy, které se jedinci dostává a podle hudebních činností, které provádí. Systematickou prací, rozvíjením hudebních předpokladů, se dospívá ke kvalitativně vyšší úrovni - k hudebním schopnostem. Franěk (2007, s. 142) připomíná:

Hudební dispozice a zejména hudební vlohy nejsou něco statického, nebot' uzrávají v průběhu vývoje jedince, „vyjevují se“ v určitých okamžicích a jsou nejpřístupnější vůči vnějšímu působení. Svéráznost spojení různých dispozic a vloh nabývá na významu zejména $\mathrm{v}$ průběhu přetváření hudebních vloh $\mathrm{v}$ hudební schopnosti a v komplex tzv. hudebnosti jedince. (s. 142)

Poledňák (1984) konstatuje, že kvantitativní rozložení hudebního nadání v populaci zhruba odpovídá známé Gaussově křivce. Na jedné straně křivky jsou řídké patologické př́ípady úplné absence nadání (mluví se o tzv. amúzii); maximum jedinců se pochopitelně vyskytuje kolem průměru. Na druhém konci křivky je určitý počet výrazných hudebních talentů a ojediněle se vyskytne hudebně geniální jedinec. (s. 236) 
Pojem talent se v české hudební psychologii používá zřídka. Kupř. u Fraňka (2007) pojem hudební talent figuruje v názvu samostatné kapitoly, definici talentu $\mathrm{v}$ jeho textu nenajdeme. Implicitně se dá $\mathrm{z}$ výkladu odvodit, že jím chápe vysoký stupeň nadání.

Podle Američanky Haroutounianové (2000b) syntetizující pohled na hudební talent ukazuje, že jde o směs: „hudebně-specifických schopností, hudebně-výkonových faktorů, snadného a uvolněného fyzického výkonu, percepčních a kognitivních funkcí; to vše ústí v tvořivou interpretaci hudby a ve tvořivé produkty" (s. 138).

Abbottová a Collins (2004) přišli s teorií o tom, jaká je cesta talentu k vynikajícím výkonům. Postulovali existenci souboru psychologických charakteristik, který označili PCDE (Psychological Characteristics of Developing Excellence). Tvrdí, že tento soubor hraje významnou roli v realizování potencialit, jimiž je nadaný jedinec vybaven. Do tohoto souboru psychologických charakteristik patří mj. dovednost zvládat nevyhnutelné zátěžové situace (např. stoupající nároky promyšleně koncipovaného nácviku praktických dovedností nebo tendence nespoléhat na vrozené dispozice a pracovat na jejich rozvíjení). Výzkum Mcnamarové a Collinse (2009) u tří skupin hudebníků konkretizoval soubor PCDE pomocí osmi psychologických charakteristik. Jsou to: jedincova vnější i vnitřní motivace k provozování hudby, ochota obětovat hudbě mnohé, stanovení si jasných cílů, rozvíjení hudební představivosti, kvalitní praxe spojená s důkladným cvičením, realistické hodnocení vlastního hudebního výkonu, sociální dovednosti (budování si sítě vztahů, získávání příležitostí), zvládání nároků (především nároků na systematickou přípravu, na veřejné vystupování).

Hudební schopnost je vyšší psychická vlastnost jedince, která je vybudována prostřednictvím hudební výchovy, hudebních zkušeností jedince i prostředím, v němž jedinec žije (Franěk, 2007). Hudební schopnost je ovlivněna i zvláštnostmi osobnosti jedince, jeho motivací, jakož i intenzitou a účinností hudebního cvičení. Sedlák a Váňová (2013) dodávají, že kategorie schopností, dovedností a návyků nejsou jen kategoriemi psychologickými, nýbrž i psychologicko-sociálními, nebot' je člověk získává v průběhu svého hudebního vývoje. Jsou jakousi „slitinou“ jednak vrozeného (přirozeného), jednak získaného výchovou. 
Je proto velmi obtížné striktně odlišit hudební vlohy od získaných hudebních schopností. Každé dítě se podle něj rodí s určitým potenciálem, který mu dovolí zvládnout určitou činnost na individuálně (tj. pro něj osobně) nejvyšší úrovni. Tuto individuálně danou úroveň dítěte ovšem nelze překročit, a to ani intelektovým vývojem, ani výchovou, ani provozovanou praxí (Franěk, 2007).

\section{Přijímací řízení na vysoké hudební školy a jeho problémy}

V České republice se přechod zájemců ze středních škol na školy vysoké přes přijímací rrízení obvykle zkoumá v obecné rovině, bez přihlédnutí ke specifikám oborů (např. Konečný, Basl, \& Mysliveček, 2010). Pokud se už přihlíží k zaměření studia, i zde zůstává široké pojetí (viz např. kategorii Umění $a$ užité umění), aniž je specifikováno zastoupení hudebního umění (Kuchař, Vojtěch, \& Klehňa, 2014). Podobnou situaci konstatují odborníci ve Velké Británii, když si stěžují, že výzkumy toho, jak studenti přecházejí ze střední školy na vysokou školu, se nezajímají o zvláštnosti jednotlivých uměleckých a humanitních oborů (Winterson \& Russ, 2008, s. 6).

V úvodu studie jsme konstatovali, že v České republice fungují tři vysoké školy, které připravují budoucí hudebníky. Hlavní část přijímacího řízení na tyto školy má rozdílné označení: talentová praktická zkouška (HAMU), talentová zkouška (HF JAMU), talentová (praktická) zkouška (FU OU). Obvykle je doplněna ještě zjištěním hudebně-teoretických, příp. i všeobecně kulturních znalostí uchazeče. Společným jmenovatelem všech tří přijímacích zkoušek je ověření uchazečova hudebního talentu a jeho předpokladů pro další rozvoj hudebnosti.

Talentová zkouška nemůže být uchazeči prominuta. Na zmíněných třech fakultách však existují mezi talentovými zkouškami určité rozdíly. Podívejme se na požadavky k přijetí do prvního stupně vysokoškolské přípravy hudebníka (do bakalářského studia), jak jsou zveřejněny na internetových stránkách dané fakulty. Výběr jsme zúžili na hru na nástroj, stranou jsme ponechali zpěv a komponování (tabulka 2). 


\section{Tabulka 2}

Srovnání podoby prijímacích zkoušek na tři české vysoké školy, na nichž se připravují hudebníci (u bakalářského studia hry na nástroj)

\begin{tabular}{|c|c|c|c|}
\hline $\begin{array}{l}\text { Srovnávací } \\
\text { kritérium }\end{array}$ & HAMU Praha & JAMU Brno & FU OU Ostrava \\
\hline $\begin{array}{l}\text { Zveřejnění seznamu } \\
\text { otevíraných } \\
\text { studijních oborů }\end{array}$ & ano & ano & ano \\
\hline $\begin{array}{l}\text { Zveřejnění počtu } \\
\text { přijímaných } \\
\text { studentů } \\
\text { u jednotlivých } \\
\text { studijních oborů }\end{array}$ & ne & ano & $\begin{array}{l}\text { Ne pro jednotlivé obory. } \\
\text { Uvádí se: Předpokládaný } \\
\text { nejvyšší počet studentů } \\
\text { přijímaných ke studiu } \\
\text { ve studijních programech } \\
\text { Hudební umění } \\
\text { a Výtvarná umění na FU } \\
\text { OU (mimo doktorské } \\
\text { studium) je 160. Platí, že } \\
\text { v závislosti na reálném } \\
\text { přidělení finančních } \\
\text { prostředků ze státního } \\
\text { rozpočtu pro OU se může } \\
\text { každý rok měnit. }\end{array}$ \\
\hline $\begin{array}{l}\text { Přijímání } \\
\text { mimořádně } \\
\text { talentovaných } \\
\text { uchazečů bez } \\
\text { maturity }\end{array}$ & $\begin{array}{l}\text { Ve zcela výjimečných } \\
\text { př́padech } \\
\text { mimořádného talentu } \\
\text { lze na Hudební } \\
\text { a taneční fakultě } \\
\text { AMU studovat i bez } \\
\text { ukončení středního } \\
\text { vzdělání. } \\
\text { Po absolutoriu studia } \\
\text { na HAMU však není } \\
\text { nárok na udělení } \\
\text { akademického titulu. }\end{array}$ & $\begin{array}{l}\text { Zmínka o této } \\
\text { možnosti } \\
\text { v materiálech } \\
\text { o přijímacím } \\
\text { řízení na HF JAMU } \\
\text { není uvedena. }\end{array}$ & $\begin{array}{l}\text { Ani v rubrice přijímací } \\
\text { řízení, ani v rubrice } \\
\text { požadavky k přijetí není } \\
\text { tato možnost explicitně } \\
\text { uvedena. }\end{array}$ \\
\hline $\begin{array}{l}\text { Zveřejnění obecných } \\
\text { kvalitativních } \\
\text { předpokladů } \\
\text { uchazeče }\end{array}$ & $\begin{array}{l}\text { Výrazný nástrojový } \\
\text { talent (předpoklady } \\
\text { pro studium zvoleného } \\
\text { nástroje), rozvinutá } \\
\text { muzikálnost, } \\
\text { všeobecné hudební } \\
\text { předpoklady (výborná } \\
\text { pamět', cit pro } \\
\text { rytmus, tempo apod.), } \\
\text { hudební představivost } \\
\text { a schopnost vystižení } \\
\text { hudebních stylů. }\end{array}$ & Nejsou uvedeny. & $\begin{array}{l}\text { Výrazný nástrojový } \\
\text { talent, muzikálnost, } \\
\text { hudební předpoklady - } \\
\text { pamět', představivost, } \\
\text { intonace, zdravotní } \\
\text { a psychické dispozice } \\
\text { pro studium zvoleného } \\
\text { nástroje. }\end{array}$ \\
\hline
\end{tabular}


Tabulka 2 (pokračování)

\begin{tabular}{|c|c|c|c|}
\hline $\begin{array}{l}\text { Srovnávací } \\
\text { kritérium }\end{array}$ & HAMU Praha & JAMU Brno & FU OU Ostrava \\
\hline $\begin{array}{l}\text { Zveřejnění obecných } \\
\text { nároků na výkon } \\
\text { u praktické části } \\
\text { talentové zkoušky }\end{array}$ & $\begin{array}{l}\text { Hra na nástroj, } \\
\text { předvedení skladeb, } \\
\text { prezentace talentových } \\
\text { a technických dispozic. } \\
\text { Není-li uvedeno jinak, } \\
\text { je podmínkou přijetí } \\
\text { výkon zpaměti. }\end{array}$ & Nejsou uvedeny. & Nejsou uvedeny. \\
\hline $\begin{array}{l}\text { Zveřejnění } \\
\text { konkrétních } \\
\text { požadavků na výkon } \\
\text { u praktické části } \\
\text { talentové zkoušky }\end{array}$ & $\begin{array}{l}\text { Zahrání určeného } \\
\text { počtu konkrétních } \\
\text { skladeb konkrétních } \\
\text { autorů (známé } \\
\text { technické } \\
\text { a interpretační } \\
\text { náročnosti) z různých } \\
\text { stylových období; } \\
\text { navíc uchazeč } \\
\text { předvede jednu } \\
\text { skladbu dle vlastního } \\
\text { výběru. }\end{array}$ & $\begin{array}{l}\text { Zahrání určeného } \\
\text { počtu konkrétních } \\
\text { skladeb } \\
\text { konkrétních } \\
\text { autorů (známé } \\
\text { technické } \\
\text { a interpretační } \\
\text { náročnosti) } \\
\text { z různých } \\
\text { stylových období; } \\
\text { navíc uchazeč } \\
\text { předvede jednu } \\
\text { skladbu dle } \\
\text { vlastního výběru. }\end{array}$ & $\begin{array}{l}\text { Zahrání určeného počtu } \\
\text { konkrétních skladeb kon- } \\
\text { krétních autorů (známé } \\
\text { technické a interpretační } \\
\text { náročnosti) z různých } \\
\text { stylových období; navíc } \\
\text { uchazeč předvede jednu } \\
\text { skladbu dle vlastního } \\
\text { výběru. }\end{array}$ \\
\hline $\begin{array}{l}\text { Zveřejnění } \\
\text { kritérií hodnocení } \\
\text { uchazečova výkonu } \\
\text { u přijímací zkoušky }\end{array}$ & $\begin{array}{l}\text { Bodování v rozsahu } \\
0-25 \text { bodů. } \\
\text { (Zjištěno z interních } \\
\text { pokynů pro přijímací } \\
\text { komise; ve veřejně } \\
\text { dostupném materiálu } \\
\text { o přijímacím řízení } \\
\text { na internetu není } \\
\text { uvedeno.) }\end{array}$ & $\begin{array}{l}\text { Bodování } \\
\text { v rozsahu } \\
0-25 \text { bodů. }\end{array}$ & $\begin{array}{l}\text { Bodování v rozsahu } \\
0-100 \text { bodů. } \\
\text { Za samotnou talentovou } \\
\text { praktickou zkoušku } \\
\text { lze získat } 50-70 \text { bodů. } \\
\text { Rozbor skladby (písemná } \\
\text { zkouška): } 5-15 \text { bodů. } \\
\text { Všeobecný kulturní } \\
\text { přehled (ústní zkouška): } \\
5-15 \text { bodů. }\end{array}$ \\
\hline $\begin{array}{l}\text { Zveřejnění } \\
\text { minimální bodové } \\
\text { hranice pro přijetí } \\
\text { uchazeče }\end{array}$ & $\begin{array}{l}\text { Pro přijetí je třeba } \\
\text { získat více než } \\
19 \text { bodů. } \\
\text { (Zjištěno z interních } \\
\text { pokynů pro přijímací } \\
\text { komise; ve veřejně } \\
\text { dostupném materiálu } \\
\text { o přijímacím řízení } \\
\text { na internetu není } \\
\text { uvedeno.) }\end{array}$ & $\begin{array}{l}\text { Minimální } \\
\text { hranice pro } \\
\text { návrh na přijetí je } \\
20 \text { bodů. }\end{array}$ & $\begin{array}{l}\text { Minimální hranice } \\
\text { pro návrh na přijetí je } \\
60 \text { bodů. Pokud uchazeč } \\
\text { nedosáhne minimálního } \\
\text { počtu bodů byt' v jedné } \\
\text { disciplíně přijímací } \\
\text { zkoušky, nesplnil } \\
\text { podmínky pro její } \\
\text { úspěšné vykonání. }\end{array}$ \\
\hline
\end{tabular}


Talentová zkouška v ČR, která je těžištěm přijímacího řízení, má charakter komisionální zkoušky. Hudební projev, hudební talent i odbornou perspektivu uchazečů hodnotí skupina odborníků-členů přijímací komise. Má to své výhody i nevýhody.

Persson (2009) upozorňuje, že komisionální zkoušení uchazečů staví na třech předpokladech: (1) odborníci dokáží (v rámci časově omezené zkoušky) rozpoznat mezi uchazeči ty slibné, nadějné; (2) ze všech aktuálních uchazečů vyberou ty, kteří jsou nejtalentovanější; (3) hlasování či konsensus jsou nejlepším způsobem rozhodování o talentu uchazečů. Přitom je zřejmé, že uvedený postup je závislý na mnoha dalších vlivech, které s identifikací hudebního talentu nemusejí vůbec souviset.

Zde jsou některé argumenty (Persson, 2009):

- velmi dobří výkonní umělci či skladatelé ještě nemusí být dobrými porotci, citlivými hodnotiteli; mívají totiž svůj vyhraněný názor na to, jak se má interpretovat konkrétní umělecké dílo;

- učitelé, kteří působí na hudební fakultě vysoké školy, se chtějí v komisi předvést; hodnotí především technické aspekty provedeného výkonu, bezchybnost provedení skladby; neocení např. originální přístup, jímž se může talent projevovat;

- členové komise bývají ovlivněni tím, kde (tj. v které instituci) uchazeč studoval a u koho konkrétně studoval; tyto údaje někdy převáží nad skutečností, jaký výkon uchazeč předvedl;

- členové komise mívají rozdílné osobní názory na to, koho považovat za hudebně talentovaného a jak se takový talent projevuje; z toho plyne, že tentýž výkon uchazeče může být posuzován podle vnitřně odlišných kritérií; hlasování pak bude svědčit spíše o kritériích, která v dané komisi převládají, než o míře perspektivnosti uchazeče.

Dubal (1985) upozorňuje, že typickými rozdíly mezi členy poroty jsou polarity mezi pohledy: akademický-umělecký, intelektuální-emoční, technický-prožitkový. Neméně důležité je, co si sami učitelé představují pod pojmem hudební talent, jak ukázal kvalitativní výzkum Jaapové a Patrickové (2014) u učitelů základních a středních škol, konzervatoří a vysokých hudebních škol. 
Obtíže, které souvisí s komisionální podobou talentové zkoušky, by se jistě daly snížit. Existuje trojí cesta: mít o uchazeči více relevantních informací, přijímací zkoušku anonymizovat, vyzkoušet psychologické testy zjištujuící míru hudebního talentu uchazečů.

První cesta říká, že je třeba mít o uchazeči mnohem více informací než slyšet pouze jeho aktuální výkon při časově omezeném přijímacím řízení. Mít podrobnější údaje o soutěžích, kterých se zúčastnil, ${ }^{2}$ o jeho umístění v soutěžích s vysokým kreditem, o názorech členů poroty atp. Jiné užitečné údaje lze vytěžit ze spolupráce vysoké školy se střední školou a s rodiči žáka (v USA se souhrnně mluví o spolupráci s komunitou). Už v r. 1998 Haroutounianová navrhla tři jednoduché posuzovací škály pro „pozorování projevů potenciálního hudebního talentu“. Jedna byla určena pro učitele hudební výchovy, druhá pro třídního učitele a třetí pro rodiče.

Při rozhodování by přijímací komisi mohly pomoci i nahrávky uchazečových výkonů z dřivější doby. Na rozdíl od talentových zkoušek na výtvarné umělecké obory se v př́ípadě hudebních oborů ani na jedné ze tří zmíněných vysokých škol nepožaduje povinně doložit přihlášku také dokladem o reálných uměleckých výkonech uchazeče $\mathrm{z}$ předchozí doby. $\mathrm{V}$ případě výtvarného umění to bývá výběr kreseb, grafik a malby, v případě hudebního umění by to mohly být nahrávky jeho hudebních výkonů.

Druhá cesta by mohla využít postupu, který se používá v prestižních hudebních soutěžích, kdy soutěžící hrají za zástěnou, takže je porota nevidí, ale pouze slyší. Nemáme však informace o tom, že by se tento anonymizovaný postup při přijímacím řízení na českých vysokých hudebních školách reálně používal.

Třetí cesta staví na psychologických testech, které zjištujuí míru hudebního talentu uchazečů a dovolují do jisté míry předpovídat budoucí úspěšnost uchazeče. Používají se především v USA. Potíž je v tom, že neexistují jejich standardizované české verze a obsah těchto testů se soustřed'uje spíše na dílčí, snadněji měřitelné aspekty hudebního talentu.

2 V některých hudebních oborech je už takový postup zaveden. Např. v Brně se každoročně odehrává soutěž pro talentované pianisty nazvaná Amadeus. Osudy těch s výrazným talentem jsou dále sledovány a odborná komunita o nich ví. (Děkujeme anonymnímu recenzentovi za upozornění na tuto užitečnou praxi.) 
S oporou o odbornou literaturu (Comeau, 2009) připomeneme pět nejznámějších. Seřadíme je abecedně a uvedeme údaj o jejich schopnosti předpovídat, o jejich predikční validitě:

- Aliferisův Music Achievement Test - College Entrance Level. Výkon v tomto testu koreluje 0,66-0,67 s prospěchem studenta v prvních dvou ročnících vysoké školy. Problémem je, že měří pouze jeden aspekt komplexního hudebního výkonu: auditivně-vizuální diskriminování.

- Drakeův Musical Aptitude Test. Jeho predikční validita je 0,55-0,58, což není mnoho. Zjištujue studentovu hudební pamět' a rytmus.

- Gastonův Test of Musicality má predikční validitu 0,52. Měří schopnost identifikovat tón v akordu, poznat rozdíl mezi slyšenou a tištěnou melodií, identifikovat rytmické změny v opakované melodii.

- Gordonův Musical Aptitude Profile. Test zjištuje tonální představivost, rytmickou představivost a hudební senzitivitu. Studenti, kteří měli sumární skóre vyšší než průměr, byli potom na škole v instrumentálních výkonech výrazně lepší než jejich spolužáci.

- Tilsonův-Gretschův Musical Aptitude Test má predikční validitu jen 0,50. Zjištuju rozpoznání tónů, změny intenzity, časové změny, tonální pamět'.

Z uvedených hodnot (kdy maximum je 1,0) je patrné, že predikční validita těchto psychologických testů je sotva průměrná a po věcné stránce samy o sobě jako podklad pro rozhodnutí nestačí. Navíc rozmezí, v němž se chyba predikce pohybuje, bývá relativně široké, takže je obtížné rozhodovat o přijetí/nepřijetí pouze na základě testových výsledků.

V odborné literatuře jsme našli jediný výzkum, který porovnával známky studentů u přijímacího řízení se známkami u závěrečných zkoušek při ukončování vysokoškolského studia hudby. Výzkum provedl Lehmann (2014) u 93 německých vysokoškoláků. Konstatoval zajímavou skutečnost, že se hodnota korelačního koeficientu výrazně liší pro jednotlivé skupiny nástrojů. Nejvyšší byla u klavíru $(0,64)$, poněkud slabší u zpěvu $(0,55)$, malá u dechových nástrojů $(0,24)$ a prakticky zanedbatelná u smyčcových nástrojů $(0,05)$. Není však jednoduché tato zjištění interpretovat a navíc šlo o jednorázovou studii.

Obecně je předpovídání dalšího vývoje uchazeče obtížné proto, že při předpovídání můžeme vycházet jen ze současné situace, z aktuálního kontextu. Nevíme však, které všechny další proměnné při vstupu zatím nepůsobí, ale mohou vstoupit do hry v budoucnu. 
V zahraničí Lancasterová (2003) doporučuje, aby vyhledávání hudebně talentovaných studentů sledovalo více hledisek, bylo vícestupňové a nebylo jednorázové. ${ }^{3}$ Mělo by podle ní zahrnovat:

1. posouzení uchazečových hudebních schopností (rozlišení tónů, pamět' pro tóny, pamět' pro rytmus, hudební senzitivitu, témbr); důležitý je také vysoký strop hudebních schopností, tedy prostor pro další rozvoj a perspektiva dosažení ještě vyšších úrovní;

2. posouzení uchazečovy hudební tvořivosti (fluency, flexibility, originality);

3. posouzení uchazečova zájmu o hudbu (dotazník pro uchazeče samotného, jeho rodiče a jeho dosavadní učitele);

4. posouzení uchazečova vývoje v učení (zjištovat jeho motivaci, nadšení a ochotu obětovat něco ve prospěch hudby, schopnost se soustředit);

5. pozorování uměleckých aktivit uchazeče (jeho výkonu, jeho uměleckých děl);

6. posouzení míry uchazečova zapojení do dalších uměleckých aktivit kromě uměleckých výkonů nebo tvorby uměleckých děl.

Přijímací řízení končí rozhodnutím o přijetí či nepřijetí uchazeče. Jsou však případy, kdy uchazeč má zřejmě talent, je určitým příslibem do budoucna, ale nesplňuje některé formální kritérium, např. ukončené středoškolské vzdělání. Tomuto případu je věnován další oddíl naší studie.

\section{Výhody a nevýhody předčasného vstupu na vysokou školu}

Při přijímacích zkouškách bývají členové přijímací komise svědky opravdu mimořádných hudebně-interpretačních výkonů vzhledem $\mathrm{k}$ věku uchazeče. Mimořádných tím, že jsou srovnatelné s výkony standardně očekávanými ve věkové kategorii o stupeň vyšší, např. výkonu adolescenta srovnatelného $\mathrm{s}$ výkonem dospělého interpreta.

V uvedených situacích se pak někdy zrodí rozhodnutí zajistit uchazeči možnost studovat o stupeň výše. Jinak řečeno: zajistit mu předčasné přijetí

3 Ve vybraných případech by se dala zvažovat i zkouška před kolegiem děkana, jako tomu bylo dříve na HAMU po absolvování 1. ročníku. 
ke studiu na umělecké škole vyššího stupně, než je ten, který mu s ohledem na jeho věk př́ísluší. Za tímto rozhodnutím komise stojí úvaha: je třeba vytvořit talentovanému jedinci takové podmínky, aby nebyl v rozvoji svého nadprůměrného talentu brzděn kolektivem méně zdatných vrstevníků. Je třeba urychlit rozvoj talentu i za cenu prominutí některých povinností.

Rozhoduje-li se přijímací komise na vysoké umělecké škole, má k udělení výjimky právní podklad. Zákon o vysokých školách dává takovýmto výjimečným talentům možnost a šanci rozvoje na vysokoškolské úrovni přijetím bez maturitní zkoušky. Zákon č. 111/98 Sb. přímo říká: „Ke studiu v oblasti umění mohou být výjimečně přijati též uchazeči bez dosažení úplného středního nebo úplného středního odborného vzdělání nebo vyššího odborného vzdělání poskytovaného v konzervatořích." (§ 48, odst. 2). Je však třeba dodat, že získání vysokoškolského titulu je už podmíněno složením maturity. Je tedy třeba, aby si takový student maturitní zkoušku doplnil, jinak mu nemůže být udělen titul BcA. ani MgA.

Jak charakterizovat ono urychlování? Urychlování vývoje bývá považováno za jednoduchou a elegantní akademickou intervenci. Jejím účelem je provést studenty předepsaným učivem bud' mnohem rychleji, anebo v mnohem mladším věku, než je obvyklé (Pressey, 1949).

Řekli jsme, že o přijetí na vysokou hudební školu rozhoduje přijímací komise. Uvažuje-li komise o prominutí maturity, bylo by užitečné, aby promýšlela určitou analogii k doporučením, která platí pro české základní a střední školy při rozhodování o tom, zda je vhodné vývoj žáka akcelerovat, urychlovat (Zapletalová, 2006). Akcelerace podle MŠMT zahrnuje dvě základní varianty: (a) předčasný vstup do vzdělávacího procesu daného stupně vzdělávání; (b) urychlení procesu vzdělávání nadaného žáka v rámci stávajícího stupně vzdělávání. Náš případ je analogií varianty (a). Dříve, než je žák zařazen předčasně do vyššího stupně vzdělávání, MŠMT považuje za nezbytné, aby škola měla odborné stanovisko školského poradenského zařízení ke zvláštnostem žáka a k úrovni jeho sociální zralosti. ${ }^{4}$

\footnotetext{
Pedagogicko-psychologické vyšetření žáka zahrnuje zejména: (a) analýzu anamnestických dat zjištěných z rodinné anamnézy; (b) zjištění osobnostních charakteristik a vlastností nadaných (včetně sociálních); (c) standardizovaný individuální nonverbální nebo verbální test kognitivních předpokladů se zaměřením na rozbor akcelerovaných výkonů žáka; (d) test tvořivosti; (e) analýzu výsledků pedagogické diagnostiky; (f) specifika práce s učivem a strategie myšlení; (g) analýzu zájmové činnosti žáka (Zapletalová, 2006, s. 13).
} 
Úvahy o urychlování vývoje talentu s sebou nesou závažnou otázku: Je tento způsob uvažování správný? Zdá se, že na takto obecně položenou otázku neexistuje jednoznačná odpověd', nebot' takovéto rozhodnutí má svá pozitiva i negativa.

Argumenty hovořící pro urychlování vývoje. Podívejme se nejprve na obecné argumenty hovořící pro akceleraci vývoje (Šimanová, 2006, s. 91):

- Talentovaný jedinec se vyhne opakování toho, co již zvládl.

- Vyhne se konfliktům s věkově stejně starými, ale schopnostně slabšími vrstevníky.

- Setká se s intelektuálně rovnými vrstevníky.

- Zvýší se jeho motivace k učení a produktivita práce.

Existují i argumenty specifické, které se opírají o dřívější zkušenosti učitelů HAMU:

- Díky svému mladšímu věku ( $\mathrm{v}$ případě kvalitního pedagogického vedení) může student stále ještě pružně rozvíjet ty složky svého talentu, které jsou u starších spolužáků již málo flexibilní, zafixované, „,zakonzervované“.

- Jedinec neztrácí čas a ve svém osobním uměleckém rozvoji postupuje rychle vpřed. Ruku v ruce s tím si rozšiřuje své obzory, pokud jde o poznávání širšího repertoáru, obecnějších kontextů historických, estetických, slohových.

- Již v raném věku má snadnější př́ístup k četným příležitostem a možnostem své umělecké prezentace. At' je to formou účasti na uměleckých interpretačních soutěžích či vystupováním na prestižních pódiích. To vše zpětně přispívá k jeho rozvoji formou nabývání cenných zkušeností.

- Dříve než jeho vrstevníci má možnosti účastnit se domácích i zahraničních stáží, workshopů, kursů a dalších akcí, pořádaných nebo zprostředkovávaných vysokou školou.

- Již jako poměrně velmi mladý získává cenné společenské kontakty a příležitosti, což je důležitá a nepostradatelná deviza pro budoucí profesionální hudební dráhu. 
Existují ovšem závažné argumenty proti urychlování vývoje. V obecné rovině je jasně formulují Colangelo a Assoulineová (2009). První skupinu obav lze označit jako akademickou, školní. Učitelé se bojí, že student, který je mladší než jeho spolužáci, není schopen se předepsané učivo naučit (je určeno pro věkově starší studenty) a nezvládne ho v jeho komplexnosti. Druhou skupinu obav můžeme nazvat sociální. Vychází z přesvědčení, že nasměrování mladšího studenta na trajektorii, která je koncipována pro vyšší ročníky a starší věkové skupiny, může být značným rizikem pro jeho sociální vývoj, pro jeho psychosociální dozrávání.

Zkušenosti učitelů HAMU z dřívějších let ukazují, že nástup na vysokou školu představuje i pro maturanta značnou psychickou zátěž, nebot’ musí zvládnout přechod do zcela odlišného stylu studia. Na vysoké škole se od studenta očekává vyšší míra samostatnosti a osobní zodpovědnosti při studiu, schopnost samostatně si systematicky organizovat čas a racionálně zvládat nápor kvantitativně mnohdy značně rozsáhlých úkolů a povinností; v četných situacích se předpokládá schopnost samostatného rozhodování. Pro patnáctiletého studenta jsou tyto situace neobyčejně náročné, není na ně zralý.

Předčasný nástup na vysokou školu představuje pro studenta, jemuž byla prominuta maturita, vytržení z kolektivu přirozených vrstevníků. Ocitá se v kolektivu studentů o 4 až 6 let starších a nepoměrně zralejších, mentálně vyspělejších. Připomeňme, že mnozí posluchači hudebních fakult nastupují do vysokoškolského studia až po 6. ročníku konzervatoře, tj. v 21 letech; rozdíl mezi spolužáky až šesti let představuje v tomto věku značný odstup.

Mezi riziky lze zmínit i studentovu nepřipravenost ke studiu odborně teoretických disciplín. U nich se předpokládá zvládnutí učiva na středoškolské úrovni, aby se při vysokoškolském studiu mohly stát předmětem i nástrojem činnosti, která je kompatibilní se studiem samotného hudebně interpretačního oboru. Středoškolský základ je v př́ípadě předčasně přijímaného uchazeče přeskočen a student si jej musí urychleně doplňovat, což bývá na úkor kvality.

Podali jsme souhrnný obraz výhod a nevýhod urychlování vývoje nadaných a talentovaných studentů. Jaká je realita, naznačují údaje, které jsme získali z matriky vysokoškolských studentů, kterou spravuje MŠMT ${ }^{5}$ (viz tabuka 3).

\footnotetext{
Děkujeme PhDr. J. Smrčkové, Ph.D. z MŠMT za poskytnutí potřebných údajů.
} 
Tabuka 3

Počty studentů, kteří byli přijati do bakalářského studijního programu Hudební umění v akademických letech 2004/2005 až 2014/2015 bez maturity

\begin{tabular}{|c|c|c|c|c|c|c|c|}
\hline \multirow{2}{*}{$\begin{array}{c}\text { student } \\
\text { č. }\end{array}$} & \multirow{2}{*}{$\begin{array}{l}\text { vysoká } \\
\text { škola }\end{array}$} & \multicolumn{4}{|c|}{ bakalářské studium } & \multirow{2}{*}{$\begin{array}{l}\text { NMgr. } \\
\text { studium } \\
\text { úspěšnost } \\
\text { NMgr. } \\
\text { studia }\end{array}$} & \multirow[b]{2}{*}{ Ph.D. studium } \\
\hline & & $\begin{array}{l}\text { zapsán } \\
\text { v roce }\end{array}$ & $\begin{array}{l}\text { ukončil } \\
\text { studium } \\
\text { v roce }\end{array}$ & $\begin{array}{l}\text { délka } \\
\text { Bc. studia } \\
\text { (roky) }\end{array}$ & $\begin{array}{l}\text { úspěšnost } \\
\text { Bc. studia }\end{array}$ & & \\
\hline 1. & $\mathrm{FU} \mathrm{OU}{ }^{6}$ & 2007 & 2011 & 3,795 & ne & - & - \\
\hline 2. & FU OU & 2007 & 2009 & 2,367 & ne & - & - \\
\hline 3. & FU OU & 2007 & 2008 & 0,575 & ne & - & - \\
\hline 4. & FU OU & 2007 & 2010 & 2,978 & ano & ano & ne \\
\hline 5. & FU OU & 2007 & 2010 & 2,934 & ano & ano & ne \\
\hline 6. & FU OU & 2008 & 2008 & 0,266 & ne & - & - \\
\hline 7. & FU OU & 2009 & 2012 & 2,712 & ano & ano & ano \\
\hline 8. & FU OU & 2009 & 2012 & 2,712 & ano & ano & ano \\
\hline 9. & FU OU & 2009 & 2012 & 2,712 & ano & ano & ano \\
\hline 10. & FU OU & 2012 & \multicolumn{5}{|c|}{ Podrobnější údaje jsou nedostupné. } \\
\hline
\end{tabular}

Tabulka 3 přináší data za posledních 11 let. Lze z ní vyčíst, že ve sledovaném období se prominutí maturity neobjevovalo ani na HAMU, ani na JAMU, ale pouze na UF Ostravské univerzity. Týkalo se 10 studentů, přičemž detailní informace jsou k dispozici o 9 studentech. Z nich 4 (44\%) nedokončili ani bakalářské studium. Celkem 5 studentů, kteří vydrželi a dohnali svůj handicap ve středoškolském vzdělání, postoupilo do navazujícího magisterského studia. Z nich se po absolvování 3 dostali do doktorského studia. Shrnuto: $\mathrm{Z}$ devíti studentů, kterým byla na počátku prominuta maturita, jich vysokoškolského studium úspěšně dokončilo $56 \%$. Svůj talent potvrdila (ze všech studentů, kterým byla na počátku povolena výjimka) jen třetina doktorským studiem.

\section{Rozvíjení hudebního talentu}

Vstupem jedinců na vysokou hudební školu práce učitelů s talentovanými studenty teprve začíná. Aniž bychom zacházeli do podrobností, připomeneme hierarchický model vysokoškolské přípravy studentů, který navrhl tým

6 Fakulta umění Ostravské univerzity. 
vedený Papageorgiovou, Haddonovou a Creechovou (2010a). Rozvoj hudebních schopností studenta má podle ní podobu pyramidy, která má tři vrstvy.

Spodní, výchozí vrstvu tvoří nutné předpoklady: hudební i osobnostní zvláštnosti studenta, institucionální kultura dané vysoké školy a pedagogické zkušenosti vyučujících. Sami bychom ještě doplnili zvláštnosti skupin studentů studujících daný obor. Střední vrstvu tvoří samotný proces vyučování a učení: rozvíjení hudebních schopností, získávání nových hudebních dovedností, rozvíjení postojů studentů k výuce a ke cvičení. Kao (2011) upozorňuje, že student musí být odolný vůči osamělosti, vypěstovat si určitou toleranci na izolaci, když se připravuje na výuku, nebot' talent se rozvíjí postupně během dlouhého období vysokoškolského studia. Musí systematicky cvičit hru na nástroj, nebot' zlepšování dovedností obvykle postupuje pomalu. Haroutounianová (2000a) konstatuje, že cílem dlouhodobého intenzivního cvičení nemůže být dosažení technické zdatnosti. Ta je pouhým předpokladem pro rozvinutí stylové interpretace skladeb a hudební tvořivosti studenta.

Nejvyšší vrstvu pyramidy tvoří výsledky učení: zaangažovanost studenta v hudebních aktivitách, jeho vnitřní motivovanost, pozitivní postoje k hudebním výkonům. Stručně řečeno: hudebně rozvinutý absolvent. Práce Papageorgiové a kol. (2010a, b) konstatovaly, že výraznou determinantou př́pravy budoucích hudebníků je kultura dané vysokoškolské instituce a my dodáváme její psychosociální klima. Vlastní průběh vysokoškolské přípravy přijatých studentů je ovšem samostatným tématem, které by si zasloužilo specifickou výzkumnou studii.

V kontextu našeho tématu - přijímacího řízení - jen připomeneme, že ani uchazeči, kteří se komisi jevili jako velmi talentovaní, nemusí být nakonec úspěšní. Pokud se podíváme na tab. 1, zjistíme, že z 9 studentů přijatých bez maturity, dva nedokončili ani první ročník studia, třetí nedokončil 3. ročník; čtvrtý si prodloužil studium téměř na čtyři roky, ale také bakalářské studium nedokončil.

\section{Závěry}

Tato studie se věnovala problémům, které řeší vysoké hudební školy, když v rámci přijímacího řízení vybírají ze souboru uchazečů ty, kteří mají talent, a předpokládá se o nich, že zvládnou nároky vysokoškolského studia hry na nástroj. 
Analýza literatury ukázala, že sám obecně psychologický pojem talent lze vymezovat čtyřmi odlišnými způsoby, které však mívají své praktické výchovně-vzdělávací dopady. Na rozdíl od zahraničí není v české hudební psychologii pojem hudební talent rozpracován do větší hloubky, není doveden až do podoby měřitelných charakteristik a toto zpoždění bude třeba postupně odstraňovat.

V České republice fungují tři hudební vysoké školy (HAMU v Praze, JAMU v Brně, FU v Ostravě) a podoba jejich přijímacího řízení, včetně talentových zkoušek se poněkud liší. Týká se to např. informací o počtu přijímaných studentů, informace o přijímání mimořádně talentovaných uchazečů bez maturity, obecných předpokladů uchazeče, kritérií hodnocení výkonu u zkoušky. Náš výklad se soustředil na talentovou část zkoušky a diskutoval výhody a nevýhody komisionální zkoušky i možnosti jejího zlepšení. Speciálním případem bývá situace, kdy mladý uchazeč projevuje mimořádný talent a komise zvažuje, zda ho přijmout k vysokoškolskému studiu, i když ještě nemá maturitu. Na základě domácích i zahraničních zkušeností studie bilancuje přednosti i slabiny takového rozhodnutí a dokládá je rozpornými výsledky 9 mimořádně přijatých studentů ostravské Fakulty umění.

Studie konstatuje, že pokud má přijímací rízení plnit dobrou predikční funkci při vybírání těch nejlepších studentů z celého souboru uchazečů, musí se opírat o mnohem širší spektrum validních informací než dosud, a uvádí některé náměty.

\section{Literatura}

Abbott, A., \& Collins, D. (2004). Eliminating the dichotomy between theory and practice in talent identification and development: Considering the role of psychology. Journal of Sports Sciences, 22(5), 395-408.

Colangelo, N., \& Assouline, S. G. (2009). Acceleration: Meeting the academic and social needs of students. In T. Balchin, B. Hymes, \& D. Mathews (Eds.), The Routledge international companion to gifted education (s. 1085-1098). Abingdon: Routledge.

Comeau, G. (2009). Piano pedagogy: A research and information guide. New York: Routledge.

Dočkal, V. (2005). Zaměřeno na talenty aneb nadání má každý. Praha: Nakladatelství Lidové noviny.

Dubal, D. (1985). The world of the concert pianist. Conversations with 35 internationally celebrated pianists. London: Victor Gollancz.

Dweck, C. S. (1999). Self-theories: Their role in motivation, personality, and development. Philadelphia: Psychology Press.

Ďurič, L. (1999). Nadanie a talent. In L. Ďurič, M. Bratská, V. S. Hotár, \& J. Pastier (Eds.), Pedagogická psychológia. Terminologický a výkladový slovník (s. 193-194). Bratislava: SPN. 
Franěk, M. (2007). Hudební psychologie. Praha: Karolinum.

Gagné, F. (2003). Transforming gifts into talents: The DMGT as a developmental theory. In N. Golangelo \& G. A. Davis (Eds.), Handbook of gifted education (s. 60-74). Boston: Allyn and Bacon.

Gagné, F. (2004). Transforming gifts into talents: The DMGT as a developmental theory. High Ability Studies, 15(2), 119-147.

Haroutounian, J. (1998). Drop the hurdles and open the doors: Fostering talent development through school and community collaboration. Arts Education Policy Review, 99(6), 15-25.

Haroutounian, J. (2000a). Teaching talented teenagers at the Interlochen Arts Academy. Journal of Secondary Gifted Education, 12(1), 39-42.

Haroutounian, J. (2000b). Perspectives of musical talent: A study of identification criteria and procedures. High Ability Studies, 11(2), 137-159.

Hř́ibková, L. (2009). Nadání a nadaní: Pedagogicko-psychologické přístupy, modely, výzkumy a jejich vztah ke školské praxi. Praha: Grada.

Jaap, A., \& Patrick, F. (2014). Teachers' concepts of musical talent and nurturing musical ability: Music learning as exclusive or as opportunity for all? Music Education Research, 1-16.

Kao, Ch. Y. (2011). The dilemma of competition encountered by musically gifted Asian male students: An exploration from the perspective of gifted education. High Ability Studies, 22(1) 19-42.

Konečná, V. (2010). Sebepojetí a sebehodnocení rozumově nadaných dětí. (Dizertační práce). Brno: Filozofická fakulta MU, Psychologický ústav.

Konečný, T., Basl, J., \& Mysliveček, J. (2010). Přechod mezi střední a vysokou školou a role různých modelů přijímacích řízení. Sociologický časopis / Czech Sociological Review, 46(1), 43-72.

Kuchař, P., Vojtěch, J., \& Klehňa, D. (2014). Přechod absolventů středních škol do terciárního vzdělávání. Praha: NUV.

Lancaster, H. (2003). Identifying the gifted in music. Bangkok: Conference of the Thai national center for the gifted and talented. Dostupné $\mathrm{z}$ http://www.helenlancaster.com/Documents/ Identifying\%20the\%20gifted\%20in\%20music.pdf

Lehmann, A. C. (2014). Using admission assessments to predict final grades in a college music program. Journal of Research in Music Education, 62(3), 245-258.

Mareš, J. (2013). Pedagogická psychologie. Praha: Portál.

Macnamara, A., \& Collins, D. (2009). More than the ' $X$ ' factor! A longitudinal investigation of the psychological characteristics of developing excellence in musical development. Music Education Research, 11(3), 377-392.

Nijs, S., Gallardo-Gallardo, E., Dries, N., \& Sels, L. (2014). A multidisciplinary review into the definition, operationalization, and measurement of talent. Journal of World Business, 49(2), 180-191.

Papageorgi, I., Haddon, E., Creech, A., Morton, F., de Bezenac, C., Himonides, E., ... Welch, G. (2010a). Institutional culture and learning I: Perceptions of the learning environment and musicians' attitudes to learning. Music Education Research, 12(2), 151-178.

Papageorgi, I., Haddon, E., Creech, A., Morton, F., De Bezenac, C., Himonides, E., ... Welch, G. (2010b). Institutional culture and learning II: Inter-relationships between perceptions of the learning environment and undergraduate musicians' attitudes to performance. Music Education Research, 12(4), 427-446. 
Persson, R. S. (2009). Elusive Muse: Understanding musical giftedness. In L. V. Shavinina (Ed.), International handbook on giftedness (s. 727-749). New York: Springer Science + Business Media.

Poledňák, I. (1984). Stručný slovník hudební psychologie. Praha: Editio Supraphon.

Pressey, S. L. (1949). Educational acceleration: Appraisals and basic problems. Columbus: Ohio State University Press.

Sedlák, F., \& Váňová, H. (2013). Hudební psychologie pro učitele. Praha: Karolinum.

Subotnik, R. F., \& Knotek, S. (2009). A positive psychology approach to developing talent and preventing talent loss in the arts and sciences. In R. Gilman, E. Scott Huebner, \& M. J. Furlong (Eds.), Handbook of positive psychology in schools (s. 433-445). New York: Routledge.

Šimanová, Z. (2006). Vzdělávací systém ve Francii a v České republice (Diplomová práce). Dostupné z https://is.muni.cz/th/53863/pedf_m/

Winterson, J., \& Russ, M. (2008). Understanding the transition from school to university in music and related subjects. Project Report. Huddersfield: University of Huddersfield. Dostupné z http://eprints.hud.ac.uk/3692/

Zákon č. 111/98 Sb., o vysokých školách. (1998). Dostupné z http://www.msmt.cz/vzdelavani/ vysoke-skolstvi/zakon-c-111-1998-sb-o-vysokych-skolach-text-se-zapracovanymi

Zapletalová, J. (2006). Informace ke vzdělávání dětí, žáků a studentů mimořádně nadaných zabezpečující realizaci ustanovení $\S 17$ zákona č. 561/2004 Sb. a části třetí vyhlášky č. 73/2005 Sb. Věstník MŠMT, 62(12), 11-14. Dostupné z http://www.msmt.cz/file/ 8604_1_1/

\section{Autoři}

Prof. PhDr. Jiří Mareš, CSc., Univerzita Karlova v Praze, Lékařská fakulta v Hradci Králové, Ústav sociálního lékařství, Šimkova 870, 50038 Hradec Králové, e-mail: mares@lfhk.cuni.cz

Prof. MgA. Vladimír Tichý, CSc., Akademie múzických umění v Praze, Hudební a taneční fakulta AMU, Katedra teorie a dějin hudby, Malostranské náměstí 13, 11800 Praha 1, e-mail: tichy@hamu.cz

\section{Musically talented adolescents and university entrance exams}

Abstract: The aim of the review paper is to describe the issues connected to identifying musical talents and to entrance exams for university programmes specialized in music. The first part introduces the terms giftedness and talent and their relationship. The second part deals with musical giftedness, musical talent, and musical skills. In the third part we analyse the entrance exams to three university programmes specialized in music in the Czech Republic (Academy of Performing Arts in Prague, Janáček Academy of Music and Performing Arts in Brno, and Faculty of Fine Arts at the University of Ostrava). The paper draws attention to the problems arising from 
the fact that the entrance exams are evaluated by a committee and suggests possible solutions. The fourth part focuses in detail on the advantages and disadvantages of accelerating the development of musically talented students, i.e. instances when students are accepted to university without having passed their secondary school leaving examinations, and supports them with data. The authors then conclude that should the entrance exams fulfil their predictive role in choosing the best applicants, they have to draw on a much broader spectrum of valid information than they do now.

Keywords: giftedness, talent, musical talent, entrance exams, university programmes specialized in music, accelerating development

Mudrák, J. (2015). Nadané děti a jejich vývoj. Praha: Grada Publishing.

Nadání je obvykle považováno za stabilní rys osobnosti, který je možno objektivně zjištovat a jehož úroveň předurčuje budoucí profesní a studijní výsledky. Tento koncept nadání se v posledních letech stal důležitou součástí českého vzdělávacího prostředí: jsou jím ovlivňovány politiky škol a dalších vzdělávacích institucí, podílí se na výchovných a vzdělávacích postupech uplatňovaných rodiči a vyučujícími a také utváří to, jak o sobě uvažují sami žáci a studenti. Kniha analyzuje limity tohoto pohledu na nadání a představuje širší rámec založený na současných výzkumech optimálních podmínek rozvoje lidského potenciálu. Nadání je zde představeno jako jev, který je vytvářen či narušován ve vztahu dítěte s druhými lidmi. Přinejmenším stejně důležitou roli jako individuální potenciál tak hraje to, jak je tento potenciál vnímán okolím dětí i dětmi samotnými a jak je na tomto základě rozvíjen. Výsledky psychologických studií jsou v knize dokumentovány př́běhy mimořádně nadaných dětí a studentů, což předkládaným závěrům dodává na čtivosti a srozumitelnosti. 